\title{
Essays in International Economics
}

\author{
PETER B. KENEN
}

PRINCETON UNIVERSITY PRESS

PRINCETON, NEW JERSEY 


\section{PRINCETON SERIES OF COLLECTED ESSAYS}

This series was initiated in response to requests from students and teachers who want the best essays of leading scholars available in a convenient format. Each book in this series serves scholarship by gathering in one place previously published articles representing the valuable contribution of a noted authority to his field. The format allows for the addition of a preface or introduction and an index to enhance the collection's usefulness. Photoreproduction of the essays keeps costs to a minimum and thus makes possible publication in a relatively inexpensive form. 
Copyright (C) 1980 by Princeton University Press

Published by Princeton University Press, Princeton, New Jersey

In the United Kingdom: Princeton University Press, Guildford, Surrey

All Rights Reserved

Library of Congress Cataloging in Publication Data will be found on the last printed page of this book

Clothbound editions of Princeton University Press books are printed on acid-free paper, and binding materials are chosen for strength and durability

Printed in the United States of America by Princeton

University Press, Princeton, New Jersey

Princeton Legacy Library edition 2019

Paperback ISBN: 978-0-691-61549-3

Hardcover ISBN: 978-0-691-65618-2 
For Joanne, Marc, Stephanie, and Judith 